\title{
長大斜張橋鋼床版の初期不整の実測データと その圧縮強度の評価
}

\author{
大橋 治一 1 ・依田 照彦 2 樋口 $\quad$ 康三 ${ }^{3}$ \\ 1正会員 工修 本州四国連絡橋公団 設計部設計第二課（\%105 東京都港区虎ノ門 5-1-5） \\ 2正会員 工博 早稲田大学教授 理工学部土木工学科（干169 東京都新宿区大久保 3-4-1) \\ 3正会員 本州四国連絡橋公団第二管理局坂出管理事務所（下762 坂出市川津町下川津4388-1）
}

長大橋では死荷重を軽減するために鋼床版を採用することが多い，世界最大の斜張橋となる多々羅 大橋の主析にも鋼床版箱析が用いられている．斜張橋の鋼床版は，床組として活荷重を直接支えるほ か, 主桁の一部を構成する重要な部材であり, ケーブル張力の水平分力により王縮力を常に受ける.

鋼床版はデッキを縦リブと横リブで補剛した構造であり，縦リブにはねじり㓮度の高いUリブが一般 に用いられているか，このような補岡板の压縮強度に関するデー夕はほとんどないのが現状である. そこで, 初期不整について実橋での調査を行い, これをもとに初期不整を考虑した弾塑性有限変位解 析を行い, 設計法として提案されている柱モデル・アプローチの適用性の評価を行った.

Key Words: orthotropic steel deck, compressive strength, initial imperfection, residual stress, elasto-plastic finite displacement method, column-model approach

\section{1. まえがき}

鋼床版箱桁を主桁とする斜張橋においては，鋼 床版は自動車の輪荷重を直接支持する床版として の役割に加えて, 主桁の一部を構成する重要な部 材でありケーブルからの水平分力により, 圧縮力 を常に受ける. 斜張橋の長大化にともない, 全体 耐荷力は主桁の座屈に支配される傾向にあること から, 主桁の座屈に対する設計は一層重要となっ ている.

近年，主析の補剛板の設計には，拡張された柱 モデル・アプローチが適用されることが多い.こ の設計法は, 図一1(a)に示すように, 長方形断面 補剛材 (平リブ) と有効幅を考慮した補剛板で構 成された仮想補剛材長 $\mathrm{L}_{\mathrm{eff}}$ のT 型ストラットを柱 とみなし, 補剛板の圧縮強度を推定する方法であ る1),2),3)。この設計法を用いることにより，道路 橋示方書の規定に従う場合に比へて以下のような 点を評価できることに特徴がある.

(1)初期たわみ, 残留応力のような初期不整の影響 を考虑することが可能である.

(2)広幅員の銅床版のように, 㑡辺拘束条件の影響 が少ない場合には補剛板の圧縮強度の精度良い推 定が可能である.

(3)横リブ剛度の影響を考虑することが可能である.
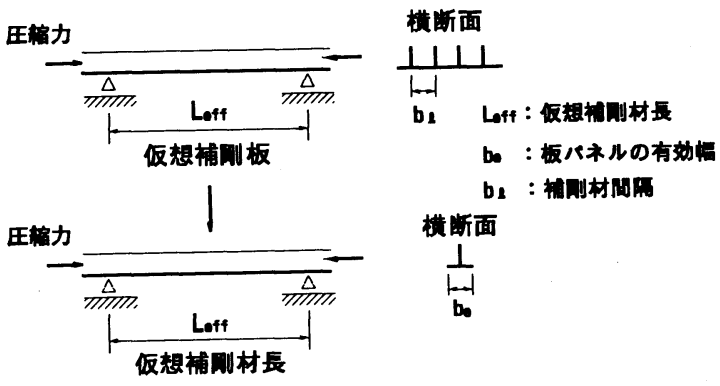

(a)縦横補剛板 (平リブ) の柱モデル・アプローチにお ける取扱い

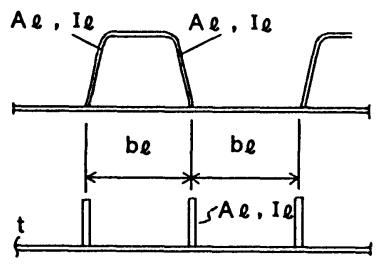

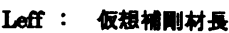

be：板バネルの有勃满

A I ： Uリプの断面辞

I : Uリブの断面二次 モーメント

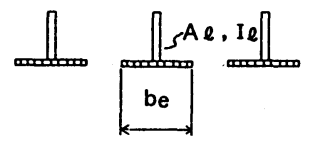

b1 : Uリプ上㲽の标 ニUリプ純成而

be : 板パネルの有奻婄

(b)Uリブ補剛板のモデル化

図ー1 柱モデル・アプローチ3) 
さらに，この設計法をU型断面補剛材（以下， Uリブと呼ぶ）に適用する場合には，図一1(b)に 示すように, 1 本のUリブを断面積および断面二 次モーメントの等価な 2 本の平リブに置換した仮 想補剛材長の極限強度を求めることになる. ここ で, 仮想補剛材長は縦横補剛板の弾性座屈強度と 等しくなるように設定されている. こうすること により, 実補剛材長と異なる仮想の補剛材長を用 いることにより横リブ剛度の影響を考慮している. このようにして求められた極限強度を所要の安全 率で割ったものが許容圧縮応力度になる.

そこで, 本論文では, 長大斜張橋の設計に柱モ テル・アプローチを適用することの妥当性を確認 するために，初期不整の実態調查および初期不整 が圧縮強度に及ぼす影響の把握を行い，柱モデル・ アプローチとの対比を行った.

\section{2. 初期不整の実測データ}

鋼床版の初期不整（初期たわみ, 残留応力）に 関する実橋での測定デー夕は少なく, 後述の弾塑 性有限変位解析に必要となるような詳細なデー夕 は特に不足している. 初期たわみに関しては, 橋 軸方向の横リブ間のたわみ等のように一部は製作 基準等により基準值が規定されているが, 圧縮強 度に及ぼす影響については明らかにされていない. また, 残留応力の大きさは使用板厚, 溶接量, 溶 接方法および組立方法により異なることが予想さ れる.

そこで，実橋の鋼床版および同等の条件で製作 された試験体を用いて初期不整を測定した.

\section{（1）初期たわみの測定}

わが国の製作基準等5)6)においては，鎆床版の 製作精度として, 橋軸方向には横リブ間隔 Lに対 してL 1,000 , 橋軸直角方向には縦リブ間隔wに対 してw/150 と規定されているが，製作管理データ としては一般に記録されていないことが多い.

\section{a ）測定方法}

初期たわみの測定を行った実橋（明石海峡大橋） の鋼床版を図一 2 に示す．材質はSS400材で，板厚 はテッキプレートが12mm，Uリブが6mmである.

Uリブとテッキプレートの溶接は脚長 $6 \mathrm{~mm}$ の片面 すみ肉溶接である. 溶接施工は標準的である多電 極 $\mathrm{CO}_{2}$ 自動溶接によって行われた.

たわみの測定は，橋軸方向に横リブ間に水糸を 張り，これを基準線として175m間隔（横りブ間 隔の $1 / 10$ 間隔）に, テッキ表面までの距離を測定 した．測定は，テッキ表面に鉛直に鋼尺（最小目 盛り $1 \mathrm{~mm}$ ) を立て, 水系とデッキ表面との距離を 計測した. 測定ラインとしては，Uリブの溶接線 上, Uリブ内中央線上およびUリブ間中央線上と した. 橋軸直角方向にはUリブ間隔の半分の150
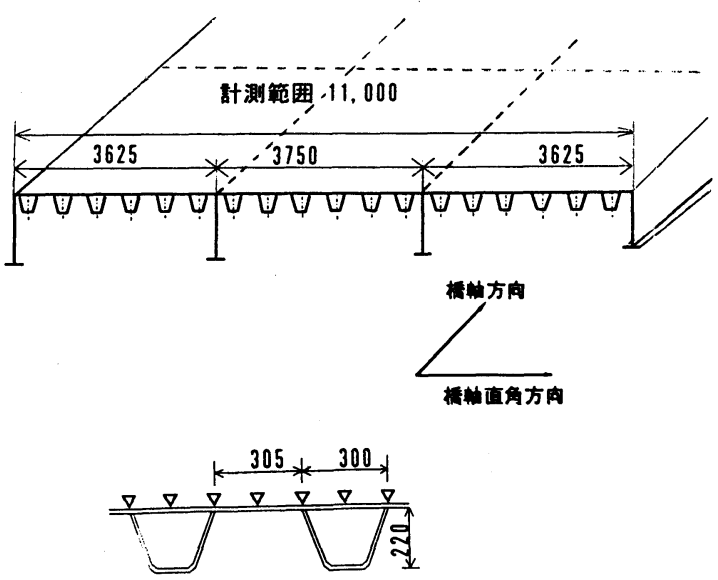

檑軸直角方向計測位量

(単位 : mm)

図一２＼cjkstart初期たわみを計測した実橋鋼床版

mm間隔で測定した.これらの測定総点数は5,183点 である.

なお，Uリブの面外たわみについては，上記の 鋼床版での計測データがなかったので, 別途, 圧 縮試験用に製作したUリブ 1 本と板パネルからな る試験体（テッッキフレート板厚 $14 \mathrm{~mm}$, Uリブ板厚 8 mm） 3 体から測定した結果を示した.

b) 測定結果

(1)橋軸方向の初期たわみ

橋軸方向の初期たわみを測定すると，横リブ間 での全体的なたわみ性状と局部的な板の凹凸が共 存してみられる. 横リブ間での初期たわみ值の橋 軸方向の分布を図一 3 に，ヒストグラムを図ー 4 に示す. 最大初期たわみを横リブ間距離Lで基準 化したたわみ比は, 平均でL/3,600（99\%限界値： L/1,200）であり，製作基準の規定值であるL $/ 1,000$ に比へて高い精度で製作されている。

隣接する補剛板での初期たわみモードに着目し て分類し，その発生頻度およびたわみ比を整理し た結果を表一 1 に示す。

最も発生頻度の高いモードは, Uリブ側に変形 する線対称のモードで，たわみ值は他のモードに 比へて大きい. 初期たわみが横リブを境に上下に 反転するモードは全体の7\%を占めている．また， 2次のたわみモードも存在するが，この場合のた わみ值は小さい.

(2)板パネルの局部の凹凸

横リブ間隔 $1.75 \mathrm{~m}$ 測定した隣接する 3 点の初期たわみから, 左右の 点を結んだ線から測った中央点の初期たわみを局 部の凹凸量として整理したものを図一 5 に示す. 


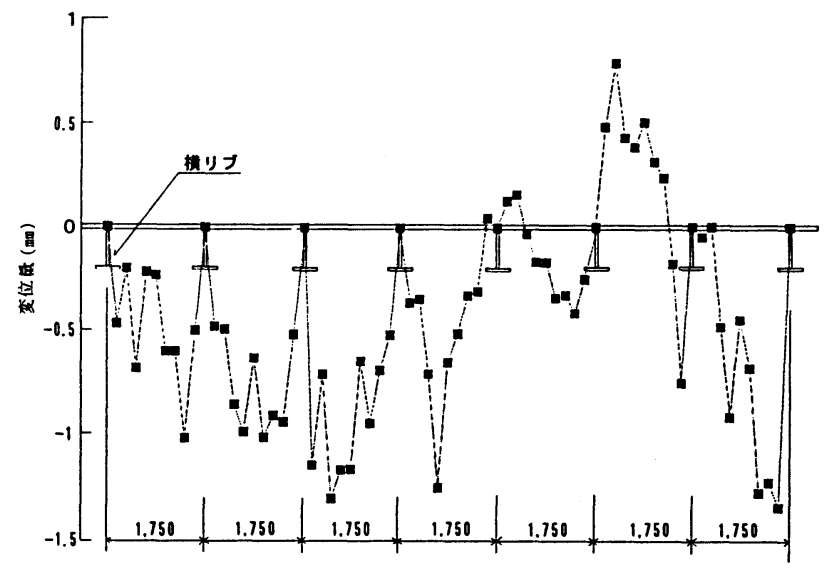

(a)Uリブ間中央点

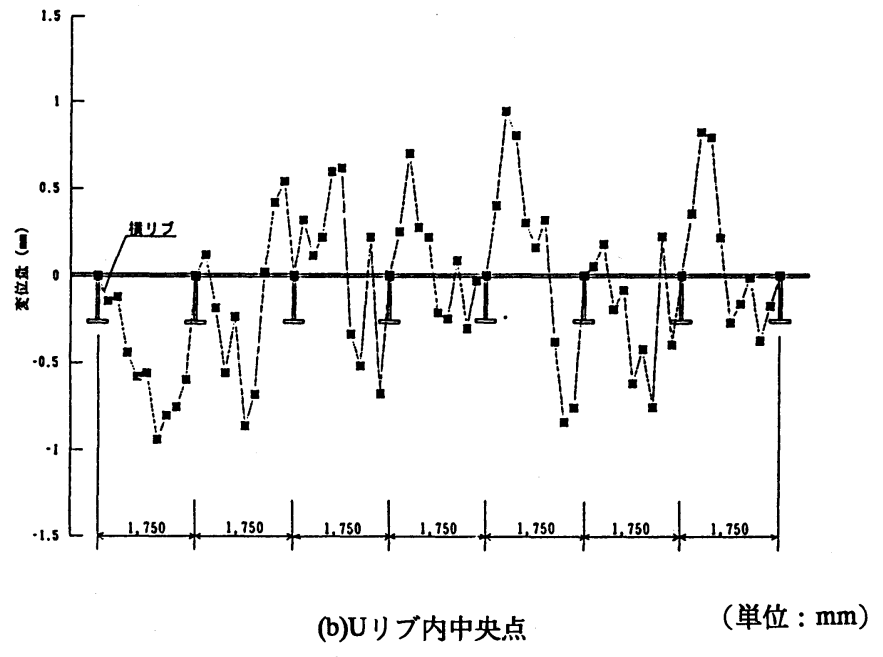

図一 3 橋軸方向の初期たわみの形状

板の凹凸量は非常に小さく, その最大値は $0.9 \mathrm{~mm}$ あった.

(3)橋軸直角方向断面内での初期面外たわみ

テッキ面にはUリブとテッキプレートとのすみ 肉溶接の影響で, 溶接線を境に面外方向に凹凸が 生じる. 測定結果の一例を図一6に，たわみ值の ヒストグラムを図ー7に示す.

全般的には，リブ間およびリブ内のデッキが下 側にたわむ傾向がみられる. たわみ值は, 平均値 でw/1,100（99\%限界值：w/400）であり，製作基 準の規定値である $\mathrm{w} / 150 に$ 比べて高い精度となっ ている.
橋軸直角方向断面内でたわみの橋軸方向の変化 としては, 橋軸直角方向断面内でのたわみが橋軸 方向に溝のように連続するのではなく, 上下方向 にも変動している（図一3(b)参照）。

(4)Uリブの板面外たわみ

Uリブをデッキに溶接することにより，Uリブ には板面外方向の変形が生じる. 別途, 圧縮試験 用に製作したUリブ 1 本と板パネルからなる試験 体によると全てUリブ内面側に変形していた.

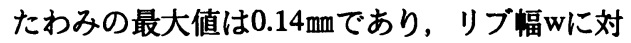
する比は平均値w/700（最大値 : w/400）であった. 
表ー 1 隣接パネル間の橋軸方向の初期たわみモードの分類

\begin{tabular}{|c|c|c|c|c|c|c|c|c|c|}
\hline & ベターン 1 & $\dot{\wedge} \not-\dot{ } 2$ & ベターン 3 & $\dot{x} \not-y 4$ & ヘターン 5 & ヘターン 6 & ヘタターン 7 & ベタ-ン 8 & ヘ்タ-ン 9 \\
\hline & & & & & & & & & \\
\hline 最大 & $L / 1000$ & $\mathrm{~L} / 1700$ & $L / 1500$ & L/1750 & $\mathrm{L} / 1600$ & $\mathrm{~L} / 1600$ & $\mathrm{~L} / \mathbf{1 7 0 0}$ & $\mathrm{L} / 1800$ & $L / 2250$ \\
\hline 平均 & L/1900 & $L / 2000$ & $L / 2400$ & $\mathrm{~L} / 3300$ & $\mathrm{~L} / 2500$ & $\mathrm{~L} / 2850$ & $L / 2700$ & L/2950 & $L / 2600$ \\
\hline $\begin{array}{l}\text { 割合 } \\
(\%)\end{array}$ & 40 & 2 & 7 & 4 & 19 & 2 & 17 & 7 & 2 \\
\hline
\end{tabular}

$\mathrm{L} ：$ 横リブ間隔, $\Delta:$ 横リブ位珇
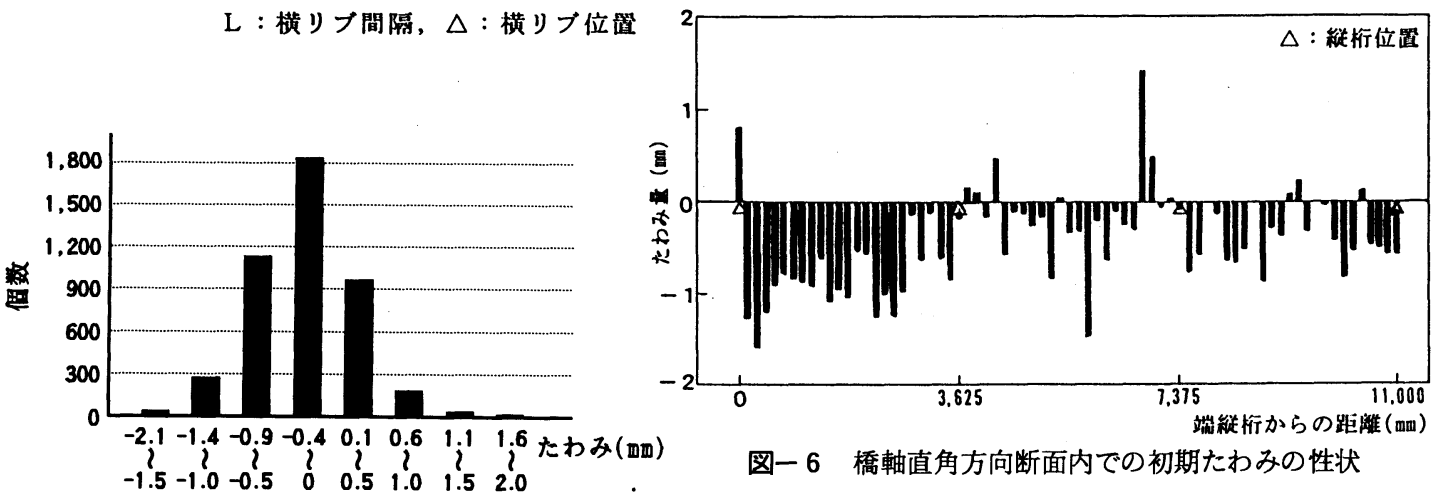

図一 4 橋軸方向の最大初期たわみのヒストグラム
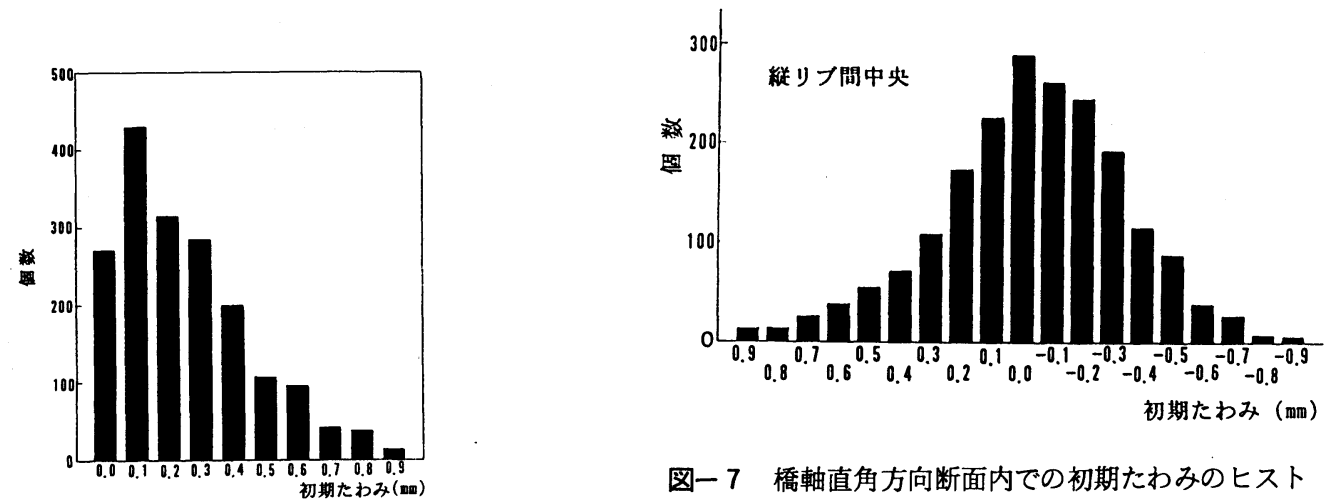

図一 7 橋軸直角方向断面内での初期たわみのヒスト グラム

図－5＼cjkstart板パネルの局部凹凸のヒストグラム

\section{（2）残留応力の測定}

残留応力の測定は，板厚構成，溶接量等の異な る 2 種類の鋼床版の試験体を用いて行った.すな わち，デッキ厚12mm，Uリブ厚6mmで構成された 疲労試験用試験体およびテッキ厚 $14 \mathrm{~mm}, U$ Uブ厚 $8 \mathrm{~mm}$ の圧縮試験用試験体である．前者は，デッキ とUリブとの溶接は開先をとらない脚長 $6 \mathrm{~mm}$ の片 面すみ肉溶接であるが, 後者は銅床版設計要領の 規定に基づき，45度の開先加工を行い，脚長 $6 \mathrm{~mm}$ の片面すみ肉溶接である.
残留応力は, 切断法により残留ひずみを測定し, 弾性平面応力問題として求めた. 計測結果を図一 8 に示すが, 残留応力の分布およびその大きさは, いづれの供試体でも同様であった．板パネルには, リブ内面側に最大一 $0.3 \sigma_{\mathrm{y}}$ の圧縮残留応力が生じ ている. この值は北田ら4)が縮尺1/3の供試体で計 測した值（一0.5 $\sigma_{\mathrm{y}}$ ）に比べると小さな值である. また, Uリブ周囲の残留応力分布は溶接部から約 $50 \mathrm{~mm}$ 離れたところに一- $0.4 \sigma_{\mathrm{y}}$ の圧縮残留応力が発 生していた. 


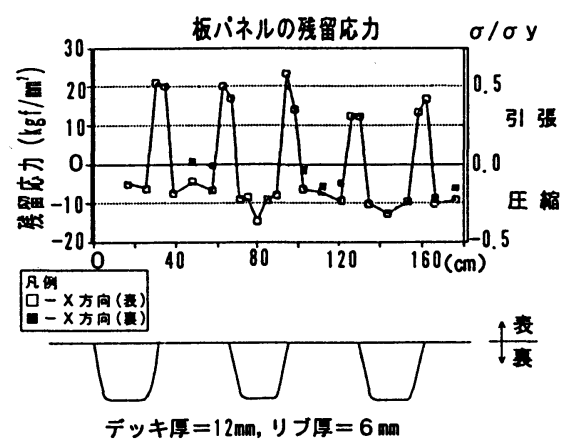

(a)疲労試験用試験体

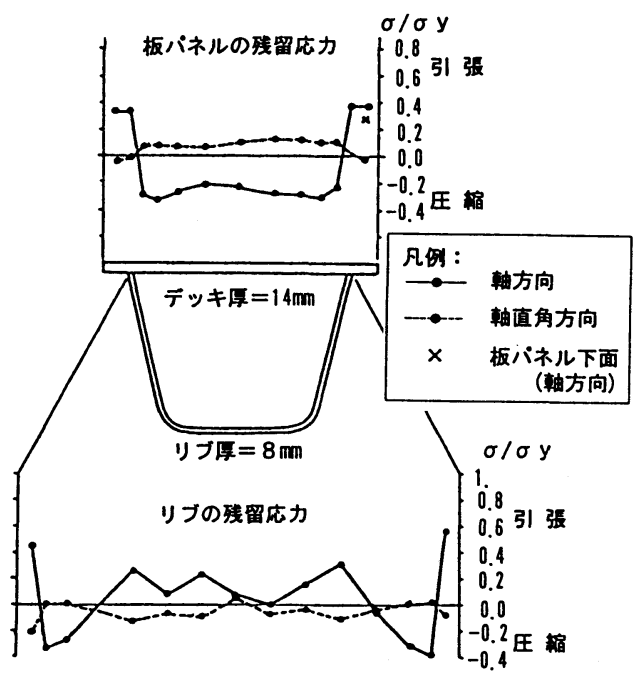

(b)圧縮試験用試験体

図-8 残留応力の測定結果

\section{Uリブ補剛板の弾塑性有限变位解析と 圧縮強度の評価}

横リブにより断面保持された連続補剛板の圧縮 強度は解析的に求めることができる.この場合, 実橋の補剛板は多リブで構成されているが，この 圧縮強度は 1 本のUリブ 亡板パネル部分を取り出 して解析できるとされている3).

解析では, 実橋の鋼床版で測定された初期たわ みおよび試験体での残留応力をモデル化し，弾塑 性有限変位解析を行った．解析プログラムは, 非 線形汎用プログラムABAQUS (Version5.2) を用い た.

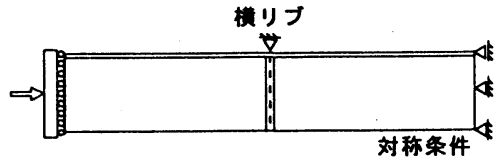

(a)橋軸方向

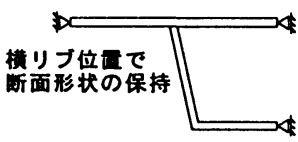

(b)橋軸直角方向

図一 9 FEM解析の境界条件

\section{（1）解析方法}

\section{a ) 解析モデル}

解析モテルの範囲は, 横リブを支点として隣接 する 2 パネルとし，対称条件を用いて断面方向に

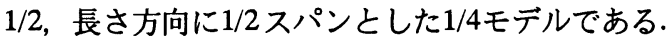
モデルの総節点数は1,421, 要素数は 442である.

板パネルとUリブとの結合条件は, 完全剛結し た場合とすみ肉溶接ビードの剛性の影響を回転バ ネとして評価した場合の解析結果に有意な差の無 いことが確認されたので, 本解析では全て剛結と して取り扱った.

使用要素は 8 節点曲面シェル要素で， 1 節点あ たり 5 自由度である. Uリブの下フランジと傾斜 しているウェブとは冷間加工による $\mathrm{R}=40 \mathrm{~mm}$ の曲 面で構成されているが，モテル化では折板で近似 した．材料はS M490Yを用いたので応力・ひずみ 曲線はバイ・リニアモデルとし, 降伏点以降は弾 性係数を1/100に低減した。降伏の判定はVon Misesの降伏条件によった，なお，Uリブの曲面部 は加工硬化により降伏点が上昇するが, 解析では 安全側を考えてこの影響を無視した。

境界条件は図一 9 に示すように，横リブ位置で Uリブの断面形状は保持されるものとし, 板パネ ルは軸方向の変位を自由とする単純支持とした.

橋軸直角方向には，図ー 2 に示すようにUリブ補 剛板が橋軸直角方向に連続していることを考慮す るために，板パネルおよびUリブの橋軸直角方向 の変位を拘束（回転は自由）した.

荷重をモテルの左端に剛体を介して作用させ， この位置での鉛直方向の変位および回転を可能と した. 右端はモデルの橋軸方向の変位を 0 とし, 鉛直方向の変位および回転を可能とした.

また，連続補剛板の解析を行うにあたって，以 下の理由から隣接する横リブ間 2 スパンをモデル 化した.

(1)圧縮力の増加により断面の塑性化が起こり，こ れにともない中立軸が移動することを正確に考虑 する必要がある.

(2)補剛材が片側にのみにある偏心圧縮柱において は, 変形がどちらの方向に進行するかによって圧 

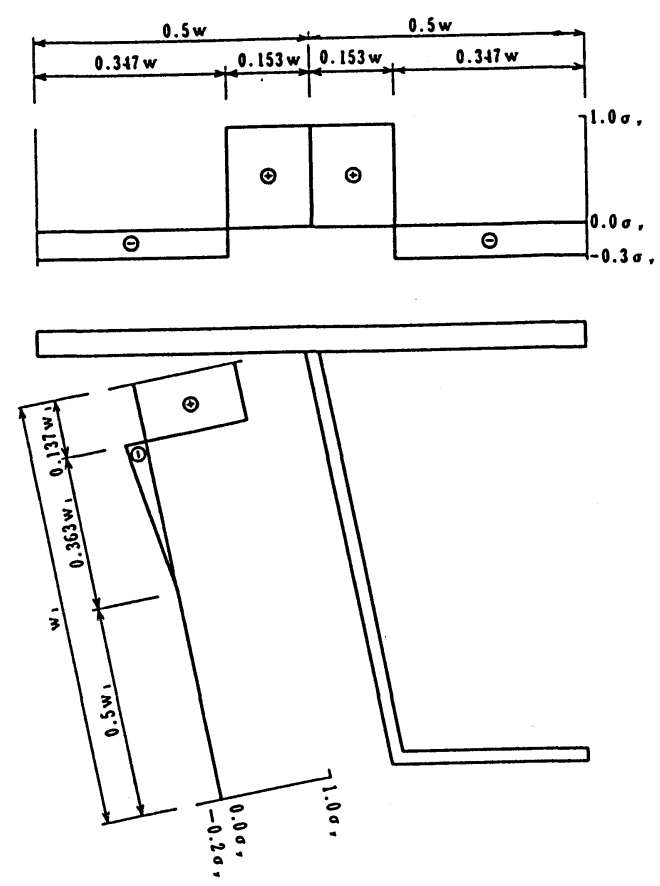

図-10 残留応力分布のモテル化

縮強度が影響を受けるため，初期たわみのモテル 化が問題となる.

これらの問題は, 連続する 2 スパンをモデル化 し，初期たわみとして横りブ位置で反転するモー ドを入れた解析を行うことにより解決することが できる3).

b) 残留応力のモデル化

残留応力は, 測定結果をもとに断面内の力の自 己平衡条件から, 図一10のような分布形状とした. c）初期たわみのモデル化

橋軸方向のたわみとしては, a ) 解析モデルの 項で述へたように，表一2の解析ケースVIIを除い て，横リブ位置でたわみが反転するモードとした. 解析ケースVIIでは，横リブ間をモデル化し，この 間に 1 次モードの初期たわみを入れた. 図ー11 は, 解析に用いた柱としての初期たわみと板パネルと しての初期たわみをそれぞれ示す. 柱としての初 期たわみモードは, 表ー 1 に示すように各種のパ ターンが存在するが, ここでは代表的な 1 次モ一 ドを示した.

橋軸直角方向断面内の初期たわみは, 橋軸方向 には正弦曲線で与えた. 初期たわみの振幅の大き さは，スパン全域に同一の振幅で与えたもの之, 図一3にみられる小波を考慮するために，横リブ 支間中央から端部に向けて減衰させたものを用い て解析した. また，製作基準におけるたわみの制 限値を参考に基本ケースを定めた.

初期たわみの測定では橋軸方向および橋軸直角 方向断面内で独立に計測しているので，これらの

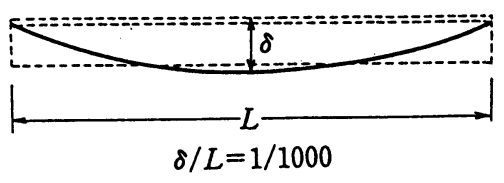

(a)柱としての初期たわみ（橋軸方向）

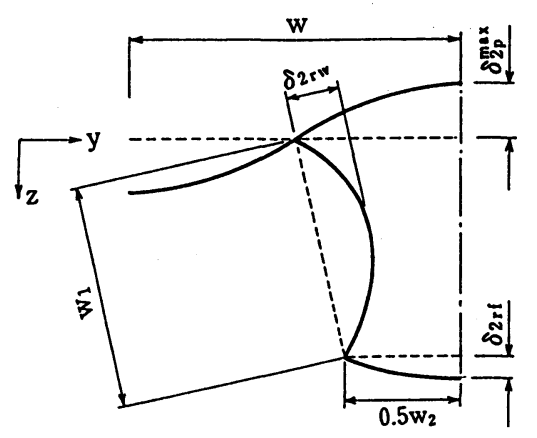

(b)板パネルとしての初期たわみ（橋軸直角方向）

図-11 個々の初期たわみのモデ化

重合わせを行う場合, 橋軸方向の初期たわみと橋 軸直角方向断面内での初期たわみとが適合するよ うに式(1)を用いて解析に使用する初期たわみを決 定した. その結果, 図ー12に示すUリブ断面の測 線(1)〜(3)着目点における初期たわみは橋軸方向 にも変化している.すなわち, Uリブの溶接線上 では橋軸方向に正弦曲線で表される初期たわみの みがモテル化されており, 小波はモテル化されて いない。これに対して，板パネルには板の凹凸が モテル化されており，Uリブ間中央位置とUリブ内 中央位置では逆方向にたわんでいる（図-12(b) 参照).

橋軸方向の波形を減衰させる場合, 鋼床版の初 期たわみの実測状況からは横りブ位置では小さく なる傾向がみられるが, それを適切にモデル化す ることが困難であるので, 解析ではモデ端（ス パン中央）から2.5波で減衰させることとした. こ れを部分減衰モデと呼ぶ.

$$
\begin{aligned}
& \delta=\frac{L / 1000}{\cos (a / 2 L)} \cos \frac{\pi x}{L} \\
& +\frac{d}{2 \cos (2 \pi / 5)} \cos \frac{\pi y}{w}\left(\cos \frac{\pi x}{5 a} \cos \frac{2 \pi x}{a}-\cos \frac{\pi x}{5 a}\right)
\end{aligned}
$$

ここに $\delta:$ 鉛直たわみ量 $(\mathrm{mm})$

$\mathrm{x}:$ 橋軸方向の位置 $(\mathrm{mm})$

$\mathrm{y}$ : 橋軸直角方向の位置 $(\mathrm{mm})$

L: 横リブ間隔 $(2,444 \mathrm{~mm})$

w:Uリブ上辺の幅 $(320 \mathrm{~mm})$

$\mathrm{d}:$ 板パネルの凹凸値 $(0.9 \mathrm{~mm})$

a: 板パネルの凹凸の橋軸方向の波長 $(350 \mathrm{~mm})$ 

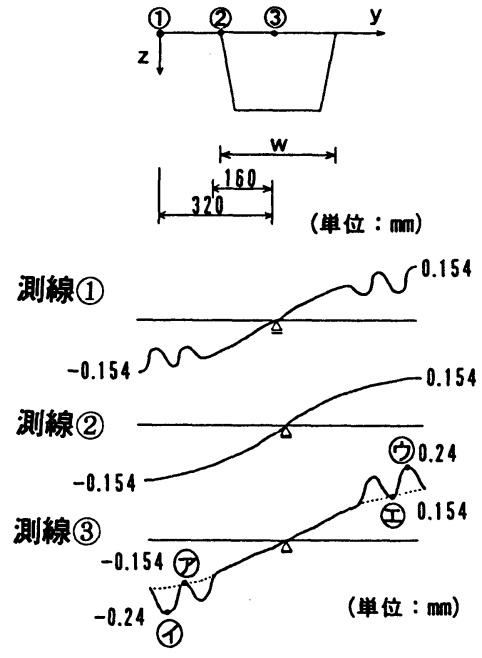

(a)(1)〜3)の測線上の初期たわみ
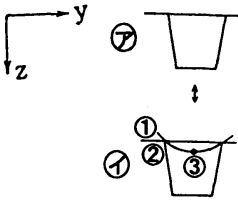

()

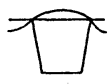

(1)

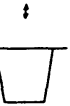

(b)板パネルの初期たわみ

図-12 橋軸方向および橋軸直角方向断面内での初期 たわみの重合わせ方法

\section{（2）解析結果}

解析結果の一覧表を表一 2 に示す. 基本ケース の崩壊モードを図ー13に示す．図一14には端部 中立軸点での平均応力・変位図を示す.

また, 板パネルおよびUリブ中央点の橋軸方向 の変位図を図-15に，終局時の塑性領域の搪がり の状況を図一16に示す.

Uリブ下フランジの上下面でのひずみの進展状 況をみると，終局荷重に達するよりも以前には局 部座屈はしていないと判断される.

以上の解析結果から次のことが考察される.

(1)基本ケースの荷重・変位の挙動（解析ケース I ） 荷重の増加にともない初期たわみモードに相似し て変位が增加し, 特に, Uリブの下フランジの圧 縮側で変位の增加が著しい．下フランジ右端から 半波長離れた位置では，変位は荷重が小さな範囲 ではプラスの方に移動するが, さらに荷重が増 加すると橋軸方向の全体的なたわみモードに支配 され，マイナスの方向に移動する. また，終局状 態ではUリブの下フランジのひずみ増分が著しい. (2)板パネルの凹凸の影響（解析ケース II）

表一 2 の解析ケースாに示すように，圧縮強度 は板パネルの局部の凹凸の有無によって支配され， 板パネルの凹凸が無い場合には圧縮強度は高い．
しかし, 板パネルの凹凸の振幅・波長はそれ程影 響を与えない。

(3)初期たわみの減衰波形の影響

橋軸方向の初期たわみの減衰波形をスパン全域 に入れた場合亡，スパン中央部付近にのみ入れた 部分減衰の場合とを比較したが，圧縮強度に差は みられなかった。

(4)初期たわみの重合わせの影響（解析ケースVII）

橋軸方向の初期たわみと橋軸直角方向断面内で の初期たわみを単純に足し合わせると，橋軸方向 の初期たわみの包絡線を大きく評価したことと等 価になる. すなわち, 橋軸方向の初期たわみL $/ 1,000$ と橋軸直角方向断面内での初期たわみw $/ 150$ を加えたものをスパンLで割ったたわみ比は L 1543に相当する. しかし，この解析結果によれば, この程度の初期たわみにおいても基本ケースに対 する強度低下はわずかであった.

(5) 2 次モードの影響（解析ケースV）

同じ大きさの初期たわみ量の 2 次モード（横リ ブ支間内に $1 つ の$ 節を有するたわみモード）導入 した場合，たわみ比としては大きいにもかかわら ず, その圧縮強度は 1 次モードに比べて高い。

(6)デッキ板厚の影響（解析ケースVII）

デッキの板厚を14mmに厚くした場合の影響はほ とんどみられなかった.

(7)Uリブ板厚の影響（解析ケースIX）

Uリブの寸法は一般に日本鋼構造協会規格によ ることが多く，その場合の最大板厚は8mmである が，Uリブ板厚を更に大きくした場合の圧縮強度 の変化を解析的に調へだ. その結果, 基本ケース に比へて圧縮強度の向上がみられた.

8)単スパンモデルの影響（解析ケースX)

連続補剛板の解析においては 2 スパンをモデル 化する必要があることは既に述べたが, モテル化 による圧縮強度による影響を把握する目的で単ス パンモテルで解析を行った. その結果, 単スパン モデルとした場合には，圧縮強度を過大に評価す る場合があることがわかった。

\section{（3）柱モデル・アプローチとの比較}

解析結果亡設計法として提案されている柱モデ ル・アプローチとの比較を行った. 柱モデル・ア プローチに用いた耐荷力曲線は座屈設計ガイドラ イン1)から引用している。 なお，この柱モデル。 アプローチでは, 残留応力の大きさはSM53に対 して0.23 $\sigma_{\mathrm{y}}$ を仮定している.

基本ケースの圧縮強度は降伏強度の $0.83 \sigma_{\mathrm{y}}$ であ り，柱モデル・アプローチの計算結果 $0.85 \sigma_{\mathrm{y}}$ とほ ぼ同等の值を与える. 初期たわみとして実測結果 の平均値を用いた場合には $0.90 \sigma_{\mathrm{y}}$ となった.

実橋で測定された最大の初期たわみおよび残留 応力を考虑した解析結果とほぼあっていることか ら, 柱モデル・アプローチの計算結果は下限值を 与えるものと考えられる. 
表ー2 Uリブ補剛板の弾塑性有限変位解析結果

\begin{tabular}{|c|c|c|c|c|}
\hline \multirow{2}{*}{ 解析ケース } & \multicolumn{2}{|r|}{ 橋軸方向のたわみ } & \multirow{2}{*}{$\begin{array}{l}\text { 橋軸直角方向断 } \\
\text { 面内でのたわみ }\end{array}$} & \multirow[t]{2}{*}{$\sigma_{u} / \sigma_{y}$} \\
\hline & 橋軸方向たわみ & 板の凹凸（波長） & & \\
\hline 1. 基本ケース & $L / 1,000$ & $d=2.1 \mathrm{~mm}(\mathrm{a}=350 \mathrm{~mm})$, 部分減衰 & $w / 150$ & 0.83 \\
\hline \multirow{4}{*}{$\begin{array}{l}\text { II. 板の凹凸 } \\
\text { (波長, 振幅) }\end{array}$} & $L / 1,000$ & $d=0.9 \mathrm{~mm}(a=350 \mathrm{~mm})$, 部分減表 & $w / 355$ & 0.83 \\
\hline & $\mathrm{L} / 1,000$ & 無し & 無し & 0.94 \\
\hline & $L / 1,000$ & $d=1.8 \mathrm{~mm}(a=350 \mathrm{~mm})$, 部分減表 & $w / 355$ & 0.83 \\
\hline & $\mathrm{L} / 1,000$ & $d=0.9 \mathrm{~mm}(a=175 \mathrm{~mm})$, 部分減衰 & $w / 355$ & 0.82 \\
\hline \multirow{2}{*}{$\begin{array}{l}\text { III. 大波 } \\
\text { (振幅) }\end{array}$} & $L / 1,500$ & $d=0.9 \mathrm{~mm}(a=350 \mathrm{~mm})$, 部分減䒾 & $w / 355$ & 0.84 \\
\hline & $L / 200$ & $d=0.9 \mathrm{~mm}(a=350 \mathrm{~mm})$, 部分減表 & $w / 355$ & 0.75 \\
\hline IV. 減表簿囲 & $L / 1,000$ & $d=0.9 \mathrm{~mm}(a=350 \mathrm{~mm})$, 全域減表 & $w / 355$ & 0.83 \\
\hline \multirow{2}{*}{$\begin{array}{l}\text { v. たわみモード } \\
\text { (2次モード) }\end{array}$} & $L / 1,000$ & 無し & 無し & 0.96 \\
\hline & $\mathrm{L} / 1,000$ & $d=0.9 \mathrm{~mm}(a=350 \mathrm{~mm})$, 部分減衰 & $w / 355$ & 0.85 \\
\hline VI. 平均たわみ伯 & $L / 3,600$ & $d=0.3 \mathrm{~mm}(a=350 \mathrm{~mm})$, 部分減衰 & $w / 1,100$ & 0.90 \\
\hline VII. たわみの重合せ & $\mathrm{L} / 543$ & $d=2.1 \mathrm{~mm}(\mathrm{a}=350 \mathrm{~mm})$ ，部分減表 & $w / 150$ & 0.82 \\
\hline UIII. テッッキ厚 $14 \mathrm{~mm}$ & $L / 1,000$ & $d=0.9 \mathrm{~mm}(\mathrm{a}=350 \mathrm{~mm})$, 部分減表 & $w / 355$ & 0.84 \\
\hline \multirow{2}{*}{ IX. リブҒ $\begin{array}{r}10 \mathrm{~mm} \\
12 \mathrm{~mm}\end{array}$} & $L / 1,000$ & $d=0.9 \mathrm{~mm}(a=350 \mathrm{~mm})$, 部分減衰 & $w / 355$ & 0.87 \\
\hline & $L / 1,000$ & $d=0.9 \mathrm{~mm}(a=350 \mathrm{~mm})$, 部分減表 & $w / 355$ & 0.92 \\
\hline \multirow{2}{*}{$\begin{array}{l}\text { x. 単スパンモデル } \\
\text { (たわみの方 : 上下) }\end{array}$} & $L / 1,000$ & $d=0.9 \mathrm{~mm}(a=350 \mathrm{~mm})$, 部分減表 & $w / 355$ & 0.91 \\
\hline & $L / 1,000$ & $\mathrm{~d}=0.9 \mathrm{~mm}(\mathrm{a}=350 \mathrm{~mm})$, 部分減表 & $w / 355$ & 0.92 \\
\hline 柱モデル・アプローチ & \multicolumn{3}{|c|}{$\mathrm{L}=2.444 \mathrm{~m}$ とした場合 （補剛材長=横リブ間隔） } & 0.85 \\
\hline
\end{tabular}

注1 L : スパン, w: Uリブ間隔, $\mathrm{d}$ : 板の凹凸, $\mathrm{a}$ : 小波の波長

注2 鋼床版の諸元: 特記なきところは, テッキ厚 $\mathrm{t}_{\mathrm{d}}=\mathrm{i} 2 \mathrm{~mm}$, リブ厚 $\mathrm{t}_{\mathrm{r}}=8 \mathrm{~mm}$, 横りブ間隔 $\mathrm{L}=2.444 \mathrm{~m}$

注3 橋軸方向のたわみを 2 次モードとした解析ケース Vの橋軸方向の初期たわみは $\mathrm{L} に$ 対する值.

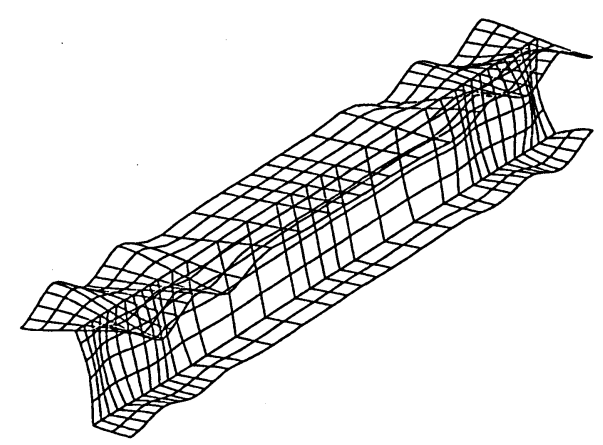

図-13 崩壊モード

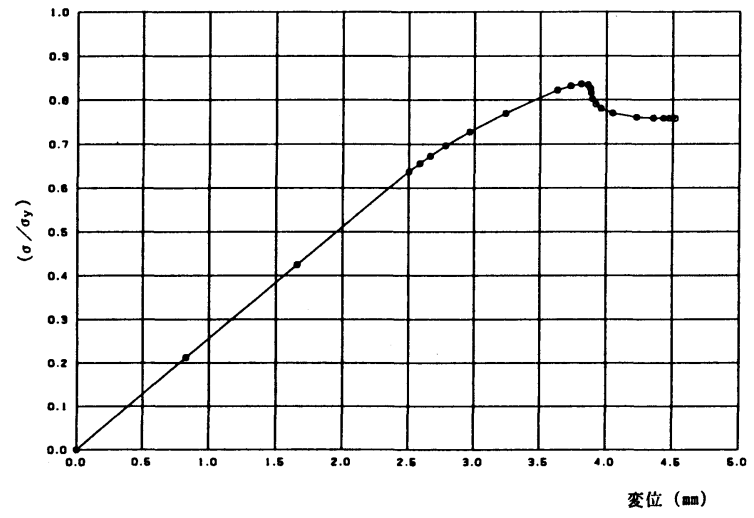

図-14 端部の中立軸点での平均応力・変位図 


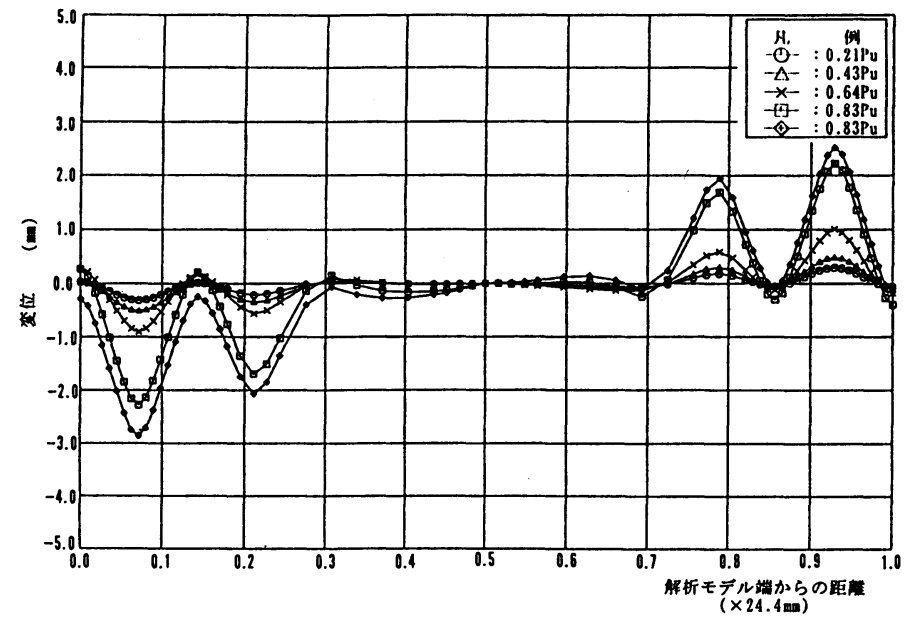

(a)Uリブ下フランジ中央点

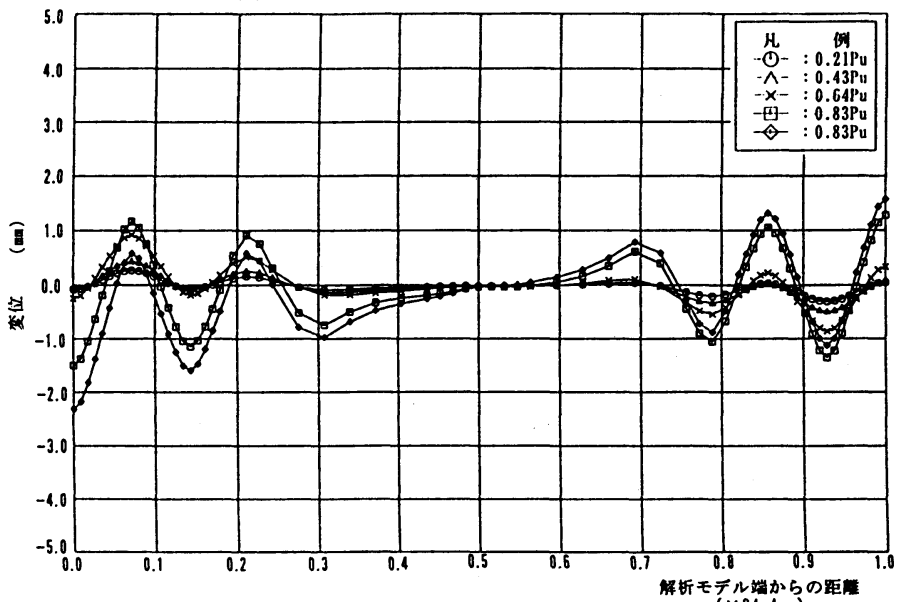

(b)板パネル中央点

図-15 着目点の橋軸方向の変位図

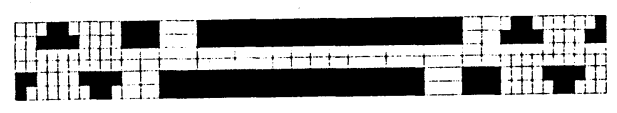

(a)板パネル上面

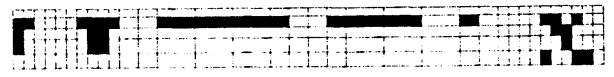

(b)Uリブウェブ内面

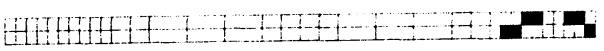

(c)Uリブ下フランジ内面

図-16 終局荷重時の塑性域の拡がり状況

\section{4. 結論}

本論文では，長大斜張橋の鎆床版として用いら れるUリブ補剛板の圧縮強度を評価するために, 実橋の初期不整の把握, その結果をもとに有限変 位弾塑性解析による圧縮強度の解析, 設計法とし て提案されている柱モテル・アプローチの適用性 について検討した. その結果, 以下のことを結論 つけりことができる.

(1)現行の製作法に基づき製作された鋼床版の初 期たわみは, 製作基準等で規定された基準値に比 べて小さな値であった.

(2)残留応力の分布および大きさについては，今 回測定した, 板厚之溶接量の異なる 2 種類の鋼床 版において有意な差はみられなかった，板パネル の圧縮残留応力の大きさは最大一 $0.3 \sigma_{\mathrm{y}}$ であった. 
(3)初期不整を考虑した弾塑性有限変位解析の結 果によると, 終局強度は板の凹凸の有無の影響は 大きいが，今回の計算例の範囲では，その凹凸の 大きさにはほとんど影響を受けない.

(4)柱モデル・アプローチの計算結果は, 実橋で 計測された初期たわみおよび残留応力を考慮した 解析結果の下限値を与えるもの之考えられる.

(5)したがって, 今回検討した幅厚比の範囲では, Uリブの局部座屈が終局強度を支配することはな いと判断される.

(6)実橋での初期不整の測定結果を考慮すると, 柱モデル・アプローチは鋼床版の圧縮強度の算出 法として安全側の值を与えるものの，鋼床版の設 計に利用することが可能であるといえる.

謝辞 : 本研究を進めるにあたり,ご指導をいただ いた本州四国連絡橋龬上部構造委員会（西野文雄 委員長) ならびに委員の方々に深く感謝の意を表 します.

\section{考文献}

1)土木学会 : 座屈設計ガイドライン, 1987年10月.

2)小松定夫, 北田俊行 : 初期不整をもつ補岡された圧縮 板の極限強度の実用計算法, 土木学会論文報告集, 第302号, 1980年10月.

3)中井博, 北田俊行, 田井戸米好, 福岡悟 : 縦 - 横補剛 材および縦桁を有する圧縮板の一設計法, 構造工学 論文集, Vol.31A，1885年3月.

4)北田俊行, 中井博, 宮坂佳洋, 古田富保 : 2 方向面内 力を受ける補剛板の極限強度に関する実験的研究, 土木学会論文集, No. 437, I-17，1991年10月.

5)本州四国連絡橋公団 : 鋼橋等製作基準, 1989年4月

6)日本道路協会 : 道路橋示方書・同解説（銅橋編） 1994 年 2 月.

7) 本州四国連絡橋公団 : 鎆床版設計要領, 1989年4月.

8)奈良敬, 小松定夫, 北田俊行 : 連続補剛板の極限強度 特性に関する研究, 土木学会論文集, NO.392, I-9, 1988年4月.

(1995. 11.20受付)

\title{
INITIAL IMPERFECTION DATA AND EVALUATION OF COMPRESSIVE STRENGTH OF ORTHOTROPIC STEEL DECK FOR LONG-SPAN CABLE-STAYED BRIDGES
}

\author{
Harukazu OHASHI, Teruhiko YODA and Kozo HIGUCHI
}

\begin{abstract}
Orthotropic steel deck has been often used for long-span bridges because of its light dead weight. The Tatara Bridge, the longest cable-stayed bridge, uses orthotropic steel deck box girder. Orthotropic steel deck used for cable-stayed bridges carries live loads as a bridge deck but is an important structural member consisting main girder to which compressive force due to horizontal component of cable tension acts. In this paper, measurement of initial imperfection on an actual deck was made, then the compressive strength of continuous deck stiffened by trough ribs was analyzed by elasto-plastic finite displacement method thereby the applicability of proposed design method of column-model approach was evaluated.
\end{abstract}

